\title{
Endogenous Cholinergic Input to the Pontine REM Sleep Generator Is Not Required for REM Sleep to Occur
}

\author{
DiD Kevin P. Grace, ${ }^{1}$ Lindsay E. Vanstone, ${ }^{2}$ and Richard L. Horner ${ }^{1,2}$ \\ Departments of ${ }^{1}$ Medicine and ${ }^{2}$ Physiology, University of Toronto, Toronto, Ontario M5S 1A8, Canada
}

Initial theories of rapid eye movement (REM) sleep generation posited that induction of the state required activation of the pontine subceruleus (SubC) by cholinergic inputs. Although the capacity of cholinergic neurotransmission to contribute to REM sleep generation has been established, the role of cholinergic inputs in the generation of REM sleep is ultimately undetermined as the critical test of this hypothesis (local blockade of SubC acetylcholine receptors) has not been rigorously performed. We used bilateral microdialysis in freely behaving rats $(n=32)$, instrumented for electroencephalographic and electromyographic recording, to locally manipulate neurotransmission in the SubC with select drugs. As predicted, combined microperfusion of D-AP5 (glutamate receptor antagonist) and muscimol $\left(\mathrm{GABA}_{\mathrm{A}}\right.$ receptor agonist) in the SubC virtually eliminated REM sleep. However, REM sleep was not reduced by scopolamine microperfusion in this same region, at a concentration capable of blocking the effects of cholinergic receptor stimulation. This result suggests that transmission of REM sleep drive to the SubC is acetylcholine-independent. Although SubC cholinergic inputs are not majorly involved in REM sleep generation, they may perform a minor function in the reinforcement of transitions into REM sleep, as evidenced by increases in non-REM-to-REM sleep transition duration and failure rate during cholinergic receptor blockade. Cholinergic receptor antagonism also attenuated the normal increase in hippocampal $\theta$ oscillations that characterize REM sleep. Using computational modeling, we show that our in vivo results are consistent with a mutually excitatory interaction between the SubC and cholinergic neurons where, importantly, cholinergic neuron activation is gated by SubC activity.

Key words: acetylcholine; microdialysis; muscarinic receptor; REM sleep; subceruleus

\section{Introduction}

Rapid eye movement (REM) sleep, characterized by vivid dreaming, motor paralysis, and heightened neural activity, is one of the fundamental states of the mammalian CNS. Despite its fundamental nature, central questions remain unanswered regarding the control system responsible for its generation.

Neuroanatomical and electrophysiological studies have delineated the brainstem site most critical to REM sleep generation. REM sleep can be eliminated by lesioning or pharmacological inactivation of the subceruleus (dorsal and $\alpha$ parts $\left(\mathrm{SubC}_{\mathrm{D} / \mathrm{A}}\right)$ ) (Carli and Zanchetti, 1965; Jones, 1979; Sanford et al., 2003; Lu et al., 2006), a region of the pons containing neurons that exhibit maximal activity in REM sleep (McCarley and Hobson, 1971; Lu et al., 2006; Sapin et al., 2009). Stimulation of the $\mathrm{SubC}_{\mathrm{D} / \mathrm{A}}$ by cholinergic receptor agonists can induce long-lasting bouts of

Received Jan. 21, 2014; revised Aug. 13, 2014; accepted Sept. 8, 2014.

Author contributions: K.P.G. designed research; K.P.G. and L.E.V. performed research; K.P.G. and L.E.V. analyzed data; K.P.G. and R.L.H. wrote the paper.

This work was supported by Canadian Institutes of Health Research (CIHR) Grant MT-15563. R.L.H. is supported by a Tier I Canada Research Chair in Sleep and Respiratory Neurobiology. K.P.G. was supported by a CIHR Doctoral Award, Fredrick Banting and Charles Best Canada Graduate Scholarship, a CIHR Team Research and Training Grant in Sleep and Biological Rhythms, and a Queen Elizabeth II/Grace Lumsden/Margaret Nicholds Scholarship in Science and Technology.

The authors declare no competing financial interests.

Correspondence should be addressed to Kevin P. Grace, Room, 3206 Medical Sciences Building, 1 King's College Circle, Toronto, Ontario M5S 1A8N, Canada. E-mail: kevin.grace@utoronto.ca.

DOI:10.1523/JNEUROSCI.0274-14.2014

Copyright $\odot 2014$ the authors $\quad 0270-6474 / 14 / 3414198-12 \$ 15.00 / 0$
REM sleep at short latencies (George et al., 1964; Hobson et al., 1983; Gnadt and Pegram, 1986; Velazquez-Moctezuma et al., 1989; Bourgin et al., 1995; Garzón et al., 1998). Consequently, initial models of REM sleep generation (e.g., the Reciprocal Interaction Hypothesis) claimed that REM sleep initiation is dependent on cholinergic activation of the $\mathrm{SubC}_{\mathrm{D} / \mathrm{A}}$ (Pace-Schott and Hobson, 2002). Consistent with this claim, the $\mathrm{SubC}_{\mathrm{D} / \mathrm{A}}$ is innervated by the cholinergic pedunculopontine and laterodorsal tegemental nuclei (PPT/LDT) (Quattrochi et al., 1989), which contain subpopulations of REM sleep-active neurons (Maloney et al., 1999). Also, SubC $\mathrm{D}_{\mathrm{A}}$ neurons are excited by acetylcholine (Shiromani and McGinty, 1986; Yamamoto et al., 1990; Sakai and Koyama, 1996) through activation of both presynaptic and postsynaptic muscarinic receptors (Weng et al., 2014).

However, interpretation of these data is cofounded by findings showing that cholinergic stimulation of the $\mathrm{SubC}_{\mathrm{D} / \mathrm{A}}$ also induces prolonged bouts of wakefulness characterized by abnormal motor behavior in cats (Mitler and Dement, 1974; van Dongen, 1980; Baghdoyan et al., 1984a) and rats (Gnadt and Pegram, 1986; Mastrangelo et al., 1994; Deurveilher et al., 1997). Also, PPT or LDT inactivation, which would be expected to reduce REM sleep, often increases or has no effect on REM sleep amounts (Torterolo et al., 2002; Lu et al., 2006; Pal and Mallick, 2009; Grace et al., 2012). Recent evidence supports an alternative claim that a combination of GABAergic disinhibition and tonic glutamatergic excitation initiates $\mathrm{SubC}_{\mathrm{D} / \mathrm{A}}$ activation and generates $\mathrm{REM}$ sleep; $\mathrm{GABA}_{\mathrm{A}}$ receptor antagonism in the $\mathrm{SubC}_{\mathrm{D} / \mathrm{A}}$ 
induces persistent REM sleep (Boissard et al., 2003; Pollock and Mistlberger, 2003) that can be terminated by codelivery of a glutamate receptor antagonist (Boissard et al., 2002).

It is important to note that, although the capacity of $\mathrm{SubC}_{\mathrm{D} / \mathrm{A}}$ cholinergic inputs to contribute to REM sleep generation has been established, existing evidence neither confirms nor refutes the necessity of $\mathrm{SubC}_{\mathrm{D} / \mathrm{A}}$ cholinergic neurotransmission in the generation of REM sleep. The contribution, if any, of endogenous $\mathrm{SubC}_{\mathrm{D} / \mathrm{A}}$ acetylcholine in REM sleep generation remains unresolved because the critical test of its involvement has never been rigorously performed. Here we report the results of that critical test: the focal antagonism of $S_{\mathrm{Sub}} \mathrm{D/A}$ muscarinic acetylcholine receptors combined with an analysis of REM sleep transition dynamics.

\section{Materials and Methods \\ Animal care}

Experiments were performed on a total of 32 male Wistar rats (Charles River) (mean \pm SEM body weight $=292.5 \pm 1.1 \mathrm{~g}$, range $280-301 \mathrm{~g}$ ). Procedures conformed to the recommendations of the Canadian Council on Animal Care, and the University of Toronto Animal Care Committee approved the protocols. Rats were housed individually, maintained on a 12-12 h light/dark cycle (lights on at $0700 \mathrm{~h}$ ), and had free access to food and water.

\section{Surgery}

Rats were chronically implanted with electrodes for recording sleepwake state: EEG and EMG of the trapezius muscle. Sterile surgery was performed as previously described (Grace et al., 2012).

Previous studies have demonstrated that the dorsolateral pontine reticular formation, ventral to the locus ceruleus and LDT, medial to the trigeminal motor nucleus, and extending from the caudal part of the ventral tegmental nucleus to the root of the facial nerve, is the region where lesioning, cholinergic stimulation, and $\mathrm{GABA}_{\mathrm{A}}$ receptor antagonism produce the greatest effects on REM sleep (i.e., the REM sleep induction zone) (for references, see Introduction). The dorsal and $\alpha$ parts of the subceruleus $\left(\mathrm{SubC}_{\mathrm{D} / \mathrm{A}}\right)$, as defined by Paxinos and Watson (1998), comprise much of this region. Therefore, we stereotaxically (model 962; David Kopf Instruments) targeted microdialysis guides (CXG-9; Eicom) bilaterally to positions $3 \mathrm{~mm}$ above the $\mathrm{SubC}_{\mathrm{D} / \mathrm{A}}(9.2$ $\mathrm{mm}$ posterior to bregma, $\pm 1.2 \mathrm{~mm}$ lateral to the midline, and $5.5 \mathrm{~mm}$ ventral to bregma). In one group of rats (Study 4, see Experimental design), an additional guide was positioned above the PPT. This guide was implanted at a $15^{\circ}$ angle relative to the sagittal plane, and the guide tip was targeted to a point $8.0 \mathrm{~mm}$ posterior to bregma, $3.34 \mathrm{~mm}$ lateral to the midline, and $2.82 \mathrm{~mm}$ ventral to bregma. Dummy cannulae were placed inside the microdialysis guides to keep them free of debris until the day of the experiment. Microdialysis probes inserted (CX-I-12-1;220 $\mu \mathrm{m}$ membrane diameter; 1 -mm-long membrane; 50,000 Dalton cutoff; $370 \mu \mathrm{m}$ shaft diameter, Eicom) projected an additional $3 \mathrm{~mm}$ into either the $\mathrm{SubC}_{\mathrm{D} / \mathrm{A}}$ or PPT. After surgery, rats were housed individually and were allowed to recover for at least $6 \mathrm{~d}$ before the experiments were performed.

\section{Habituation and recording environment}

The evening before the first study day, rats were placed in the recording environment and connected to a lightweight counterbalanced recording cable for habituation purposes. The recording environment consisted of a large open-topped bowl (Rodent Bowl, MD-1514, BAS) mounted on a turntable (Rat Turn, MD-1404, BAS), housed within an electrically shielded and soundproofed cubicle (EPC-010, BRS/LVE). A video camera located within the cubicle allowed for continuous visual monitoring without disturbing the animal.

\section{Microdialysis}

Also during the evening before the first study, the internal cannulae were removed from their guides, and microdialysis probes were inserted. Mi- crodialysis probes will cause tissue damage along the insertion track (e.g., probes inserted into the $\mathrm{SubC}_{\mathrm{D} / \mathrm{A}}$ pass through the locus ceruleus in some cases). However, because we used a repeated-measures design for all studies (see Experimental design), tissue damage is not a likely explanation for differences between control and drug treatment conditions. Moreover, we included positive controls in the experimental design to show that targeted structures can be predictably modulated despite tissue damage.

The probes were connected to FEP Teflon tubing (inside diameter, $0.12 \mathrm{~mm}$ ) with this tubing connected to $1.0 \mathrm{ml}$ syringes via a zero dead space switch (Uniswitch, BAS). The probes were perfused with freshly made ACSF at a flow rate of $2.1 \mu \mathrm{l} / \mathrm{min}$. The composition of the ACSF was as follows (in mM): $125 \mathrm{NaCl}, 3 \mathrm{KCl}, 2 \mathrm{CaCl}_{2}, 1 \mathrm{MgSO}_{4}, 25 \mathrm{NaHCO}_{3}$, and 30 glucose. The ACSF was warmed to $37^{\circ} \mathrm{C}$ and bubbled with $\mathrm{CO}_{2}$ to a $\mathrm{pH}$ of 7.4. It is important to note that fluid was not injected into the tissue; rather, the semipermeable cuprophan membrane at the tip of the microdialysis probe permits passive diffusion only.

\section{Experimental design}

Details common to all studies. All studies had a repeated-measures design and consisted of a control period (ACSF) and one or more periods of drug microperfusion. All treatment periods took place on separate but consecutive days, between the hours of 1:00 PM and 4:00 PM to control for potential circadian variation. Signals were recorded continuously during these hours. All SubC $\mathrm{D} / \mathrm{A}_{\mathrm{A}}$ treatments were administered bilaterally. Treatment order was always alternated, with the exception of Studies 1 and 4 where the control period always took place on day 1 . All rats were killed on the final treatment day, and their brains were removed to determine the position of microperfusion sites. The locations of these sites were recorded on standard coronal drawings from the stereotaxic atlas of the rat brain prepared by Paxinos and Watson (1998). In experiments targeting the PPT, the location of cholinergic PPT neurons was determined using NADPH-diaphorase histochemical staining. Histological procedures have been previously described (Grace et al., 2012).

Study $1(\mathrm{n}=4)$ (positive control). In Study 1, we sought to confirm the efficacy of muscarinic receptor antagonism at the $\mathrm{SubC}_{\mathrm{D} / \mathrm{A}}$. Study 1 consisted of three microperfusion treatment conditions: (1) ACSF control, (2) cholinergic receptor agonist alone (carbachol, $0.5 \mathrm{~mm}$, Tocris Bioscience), and (3) a combination of carbachol $(0.5 \mathrm{~mm})$ and a muscarinic receptor antagonist (scopolamine hydrobromide, $1 \mathrm{~mm}$, Tocris Bioscience). In the third condition, scopolamine was preapplied for $1 \mathrm{~h}$ (i.e., 1:00 PM to 2:00 PM) before beginning microdialysis perfusion of the carbachol-scopolamine mixture. The concentration of scopolamine needed to counteract the effect of carbachol was determined in pilot studies. We chose a concentration of carbachol that would be comparable with doses used in previous microinjection studies (range 0.4-9.0 $\mu \mathrm{g})$. We have previously shown, using a flow rate of $2.1 \mu \mathrm{l} / \mathrm{min}$, that $\sim 18 \%$ of the drug delivered to the microdialysis probe tip diffuses into the surrounding tissue (Grace et al., 2014). Therefore, a concentration of $0.5 \mathrm{~mm}$ is approximately equivalent to a $1.8 \mu \mathrm{g} / \mathrm{h}$ dose of carbachol.

Study $2(\mathrm{n}=7)$ (positive control). As anticipated from previous studies (for references, see Introduction), cholinergic stimulation of the $\mathrm{SubC}_{\mathrm{D} / \mathrm{A}}$ (Study 1) produced abnormal motor behavior and prolonged bouts of wakefulness (see Results). These effects are consistent with our having activated interspersed cholinoceptive reticulospinal neurons involved in motor facilitation and locomotion (Lai and Siegel, 1991). We then sought to confirm that, free of the confounding effects of activating supraspinal motor networks, we were accurately targeting the REM sleep induction zone and that we could predictably modulate its activity using drug microperfusion. Therefore, we broadly inactivated the region by blocking endogenous excitatory neurotransmission while simultaneously stimulating inhibitory receptors. Glutamatergic drives onto pontine neurons mediating increased muscle tone and locomotion are sensitive to NMDA receptor antagonism. Accordingly, Study 2 consisted of two dialysis treatment conditions: (1) ACSF control and (2) a NMDA receptor antagonist (D-AP5, $200 \mu \mathrm{M}$, Tocris Bioscience) together with a $\mathrm{GABA}_{\mathrm{A}}$ receptor agonist (muscimol, $10 \mu \mathrm{M}$, Tocris Bioscience).

Study 3 ( $\mathrm{n}=14)$. In Study 3, we sought to determine the role of endogenous cholinergic input to the $\mathrm{SubC}_{\mathrm{D} / \mathrm{A}}$ in REM sleep generation. 
Study 3 consisted of two dialysis treatment conditions: (1) ACSF control and (2) scopolamine alone (1 mM; the effective concentration determined in Study 1).

Study $4(\mathrm{n}=7)$. In Study 4 , we sought to corroborate the role of $\mathrm{SubC}_{\mathrm{D} / \mathrm{A}}$ cholinergic input in REM sleep generation suggested by Study 3. Study 4 consisted of three microperfusion treatment conditions: (1) ACSF microperfusion at both the $\mathrm{SubC}_{\mathrm{D} / \mathrm{A}}$ (bilateral) and PPT (unilateral), (2) urotensin-II (4 pM, Tocris Bioscience) microperfusion at the PPT along with ACSF microperfusion at the $S_{\mathrm{Db}} \mathrm{C}_{\mathrm{D} / \mathrm{A}}$, and (3) urotensin-II microperfusion at the PPT and simultaneous scopolamine $(1 \mathrm{mM})$ microperfusion at the $\mathrm{SubC}_{\mathrm{D} / \mathrm{A}}$. Urotensin-II is a neuropeptide that has been shown to selectively excite PPT cholinergic cells in vitro and increase REM sleep when applied locally to the PPT in vivo (HuitronResendiz et al., 2005).

\section{Signal processing}

Electrical signals were amplified and filtered (Super-Z head-stage amplifiers and BMA-400 amplifiers/filters, CWE). The EEG was filtered between 1 and $100 \mathrm{~Hz}$, whereas the neck EMG was filtered between 100 and $1000 \mathrm{~Hz}$. The moving-time average of the neck EMG (time constant $=50$ $\mathrm{ms}$ ) was also obtained (model MA 821, CWE). All signals were digitized at $2000 \mathrm{~Hz}$ (Spike 2 software, 1401 interface, CED).

\section{Signal analyses}

EMG and EEG signals. The data were analyzed in consecutive $5 \mathrm{~s}$ timebins. Moving-time averages of the neck EMG signals were quantified in arbitrary units relative to electrical zero defined as the voltage recorded with the amplifier inputs grounded. The EEG signal was subjected to a fast-Fourier transform for each $5 \mathrm{~s}$ time bin. The power in frequency bands ( $2 \mathrm{~Hz}$ in width) spanning the 1 to $33 \mathrm{~Hz}$ range was calculated.

Identification of sleep-wake states. Sleep-wake states were identified by visual inspection, and classified into wakefulness, non-REM (NREM), and REM sleep according to standard criteria.

NREM-to-REM sleep transition dynamics. NREM-to-REM sleep transition dynamics were analyzed using a state-space analysis (Gervasoni et al., 2004; Diniz Behn et al., 2010). The objective of a state-space approach is to create a 2-dimensional plot bounded by electroencephalographic variables that correlate with sleep-wake state, in which the position of a single point represents the electroencephalographic state of the forebrain during a single recording epoch. Spectral power in the $1-19 \mathrm{~Hz}$ frequency range and the ratio of spectral power in the $7-9 \mathrm{~Hz}$ and the $1-9 \mathrm{~Hz}$ frequency ranges were used to create state-space plots. Data were smoothed before plotting using a 5-epoch-wide moving average (MATLAB R2013b, MathWorks, function: smooth). To analyze NREMto-REM sleep transitions, we needed to define standardized boundaries of the NREM and REM sleep state-space clusters. To create the boundaries, we: (1) calculated local point densities from state-space plots using Voronoi tessellation; (2) applied a density threshold to isolate the two high-density clusters (i.e., NREM and REM sleep regions) from the surrounding low-density region; and (3) lastly plotted the convex envelope (i.e., the minimum convex area enclosing a group of points) for each cluster. We were then able to define the duration of NREM-to-REM sleep transitions as the time interval between crossings of the NREM and REM sleep convex envelopes (i.e., transition boundaries). Attempted NREMto-REM sleep transitions were defined as state-space trajectories that: (1) cross the upper third of the NREM sleep transition boundary (i.e., the boundary region where successful NREM-to-REM sleep transitions enter transition space), (2) remain in intermediate transition space for at least three epochs, but (3) never cross the REM sleep transition boundary.

\section{Neural circuit simulations}

The wiring diagram of the modeled circuit is shown in Results. The rationale for its topology is detailed as follows. The circuit supports the generation of two states, which we are calling "NREM" and "REM sleep," separated by a transitional period. The state of "REM sleep" is defined as the period when firing rate of the model " $\mathrm{SubC}$ D/A" pool is stable at a maximum level. As previously mentioned in the Introduction, the $\mathrm{SubC}_{\mathrm{D} / \mathrm{A}}$ is the critical site of REM sleep generation in vivo. Also, the $\mathrm{SubC}_{\mathrm{D} / \mathrm{A}}$ is the principal source of phenomenological outputs in REM sleep; lesioning $\mathrm{SubC}_{\mathrm{D} / \mathrm{A}}$ septal afferents eliminates hippocampal $\theta$ oscillations in REM sleep, whereas lesioning of more ventrally located $\mathrm{SubC}_{\mathrm{D} / \mathrm{A}}$ neurons projecting to the medullary reticular formation and spinal cord prevents REM sleep motor atonia (Lu et al., 2006). Based on $\mathrm{c}$-fos immunostaining, REM sleep-active $\mathrm{SubC}_{\mathrm{D} / \mathrm{A}}$ neurons are predominately glutamatergic (Clément et al., 2011); therefore, all projections of the "SubC $\mathrm{D}_{\mathrm{D} / \mathrm{A}}$ " pool in our model are excitatory. Conversely, the state of "NREM sleep" is defined as the period of "SubC $\mathrm{D}_{\mathrm{D} / \mathrm{A}}$ " inactivity (i.e., no spiking). The "NREM-to-REM sleep" transition is defined as the period over which "SubC $C_{\mathrm{D} / \mathrm{A}}$ " firing rate accelerates from the minimum to the maximum level. As previously mentioned, $\mathrm{SubC}_{\mathrm{D} / \mathrm{A}}$ activation in vivo critically requires the combination of GABAergic disinhibition and tonic glutamatergic excitation (Boissard et al., 2002, 2003; Pollock and Mistlberger, 2003). Therefore, the "SubC $\mathrm{D}_{\mathrm{D} / \mathrm{A}}$ " pool of our model receives a tonic excitatory input and an inactivating inhibitory input (termed $\mathrm{REM}$-off) responsible for initiating " $\mathrm{SubC}_{\mathrm{D} / \mathrm{A}}$ " activity. The likely source of REM-off GABAergic input to the $\mathrm{SubC}_{\mathrm{D} / \mathrm{A}}$ in vivo is GABAergic REM sleep-inactive neurons in the ventrolateral periaqueductal gray (vlPAG) and the adjacent deep mesencephalic reticular nucleus (DpMe); inactivation of these regions potently increases REM sleep in cats (Sastre et al., 1996; Crochet et al., 2006) and rats (Lu et al., 2006; Sapin et al., 2009). The vlPAG and DpMe also contain large numbers of REM sleep-active GABAergic neurons (Sapin et al., 2009). In our model, we adopt the hypothesis of Sapin et al. (2009), that REM-off and REM-on GABAergic vlPAG/DpMe neurons mutually inhibit one another. So, in our model, the REM-off pool inhibits and is inhibited by a REM-on pool. The source of inhibition to the REM-off pool is a graded analog input neuron that represents the buildup of "REM sleep" drive/propensity. With this arrangement, activation of the REM-on pool is not strictly necessary for "REM sleep" generation; this is consistent with the finding that simultaneous inhibition of overlapping REM-on and REM-off vlPAG/DpMe pools increases REM sleep (Sapin et al., 2009). Nevertheless, mutual inhibition performs a necessary function: the conversion of graded inputs (i.e., REM sleep drive signals) into a two-state output having only a brief transition period (i.e., bistability) (Brandman et al., 2005; Brandman and Meyer, 2008).

In vivo, the $\mathrm{SubC}_{\mathrm{D} / \mathrm{A}}$ innervates the vlPAG/DpMe region, and so the model circuit also includes an excitatory projection from the "SubC $/ \mathrm{D} / \mathrm{A}$ " pool to the REM-on pool (Lu et al., 2006). Because REM sleep-active $\mathrm{SubC}_{\mathrm{D} / \mathrm{A}}$ neurons are predominately glutamatergic, we would expect their input to the vlPAG/DpMe region to activate REM-on rather than REM-off neurons.

In vivo, the $\mathrm{SubC}_{\mathrm{D} / \mathrm{A}}$ and cholinergic $\mathrm{PPT} / \mathrm{LDT}$ reciprocally innervate one another, and $\mathrm{SubC}_{\mathrm{D} / \mathrm{A}}$ neurons are excited by cholinergic receptor agonism (Shiromani and McGinty, 1986; Quattrochi et al., 1989; Semba et al., 1990; Yamamoto et al., 1990; Semba and Fibiger, 1992; Sakai and Koyama, 1996). Accordingly, our model circuit includes a positive feedback loop between the "SubC $\mathrm{D}_{\mathrm{D} / \mathrm{A}}$ " pool and a "PPT/LDT" pool. We hypothesized that the effects of $\mathrm{SubC}_{\mathrm{D} / \mathrm{A}}$ cholinergic receptor antagonism in vivo were due to the interruption of this positive feedback interaction. We therefore expected similar effects when mimicking in vivo cholinergic receptor antagonism in silico, by varying the weight of synaptic inputs from the "PPT/LDT" pool to the "SubC $\mathrm{D}_{\mathrm{D} / \mathrm{A}}$ " pool.

The model circuit was created and simulated using Circuit SIMulator (Natschlager et al., 2003) (CSIM, www.lsm.tugraz.at) interfaced with MATLAB R14. The circuit is made up of leaky integrate-and-fire type model neurons (Stein, 1965; Knight, 1972; Burkitt, 2006; Brunel and van Rossum, 2007) for which membrane potential $\mathrm{v}(t)$ is given by the following:

$$
\tau_{\mathrm{m}} \frac{d \nu}{d t}=-\nu(t)+R I_{\text {syn }}(t)
$$

where $\tau_{\mathrm{m}}$ is the membrane time constant, $R$ is the membrane resistance, and $I_{\text {syn }}$ is the current supplied by the input synapses. As with all integrate and fire neuronal models, spikes are not explicitly modeled; rather, when membrane potential reaches a set threshold, a spike is registered and membrane potential immediately resets to a defined reset potential.

The REM-on, REM-off, "SubC $\mathrm{D} / \mathrm{A}$ " and "PPT/LDT" pools contain 4, 4,2 , and 1 neuron, respectively. Neuron parameters were identical in all 
cases except for the REM-off pool where the membrane resistance parameter was varied to produce neurons having different intrinsic excitabilities (needed to produce dynamic "NREM-to-REM" transitioning). Synaptic weights were set heuristically. Model parameters were constrained to produce neuronal firing frequencies of $\leq 20 \mathrm{~Hz}$.

\section{Statistics}

Data are presented as mean \pm SEM. unless otherwise indicated. The analyses performed for each statistical test are included in the text where appropriate. For all comparisons, differences were considered significant if the null hypothesis was rejected at $p<0.05$ using a two-tailed test. Where post hoc comparisons were performed after repeated-measures ANOVA, the Bonferroni-corrected $p$ value was used to test statistical significance. All analyses were performed using SigmaStat (SPSS).

\section{Results}

Our main objective was to determine the role of endogenous cholinergic input to the $\mathrm{SubC}_{\mathrm{D} / \mathrm{A}}$ in the generation of REM sleep using local muscarinic receptor antagonism. To that end, in Study 1 we determined the concentration of antagonist required to block the effects of exogenous cholinergic $\mathrm{SubC}_{\mathrm{D} / \mathrm{A}}$ stimulation with the expectation that this concentration would be sufficient to effectively block endogenous cholinergic neurotransmission.

Consistent with previous reports, microperfusion of the cholinergic receptor agonist carbachol in the $\mathrm{SubC}_{\mathrm{D} / \mathrm{A}}$ produced near-constant wakefulness characterized by abnormal motor behavior in all rats (Fig. $1 A, B$, example hypnograms, $C$, group data; ACSF vs carbachol treatment, $t_{(3)}=14.25, p<0.001$, post hoc paired $t$ test after identification of significant interaction between the factors of treatment and state: $F_{(4,12)}=75.06, p<0.001$, two-way repeated-measures ANOVA). Abnormal motor behavior included hyperactive circling, forceful kicking of the hind limbs, explosive jumping, and immobility accompanied by tetanic-like muscle contraction. Importantly, the induction of wakefulness and irregular motor behavior was completely blocked by coadministration of the muscarinic receptor antagonist scopolamine at a concentration of $1 \mathrm{~mm}$ (Figure $1 D$, example hypnogram; $C$, group data; ACSF vs carbachol/scopolamine mixture, $t_{(3)}=0.33, p=0.751$, post hoc paired $t$ test after identification of significant interaction between the factors of treatment and state; detailed above).

In Study 2, to confirm our ability to effectively target and predictably modulate REM sleep circuitry in the $\mathrm{SubC}_{\mathrm{D} / \mathrm{A}}$ free of the confounding effects of motor excitation, we broadly inactivated the region by microperfusing a combination of D-AP5 (NMDA receptor antagonist, $200 \mu \mathrm{M})$ and muscimol $\left(\mathrm{GABA}_{\mathrm{A}}\right.$ receptor agonist, $10 \mu \mathrm{M})$. REM sleep amount, as a percentage of the total recording time, was suppressed $92.2 \%$ relative to ACSF controls. (Fig. $1 E$, example hypnogram; $F$, group data; $t_{(6)}=2.24$, $p=0.045$, post hoc paired $t$ test after identification of significant interaction between the factors of treatment and state: $F_{(2,12)}=$ $7.36, p=0.008$, two-way repeated-measures ANOVA), whereas NREM sleep time increased significantly $\left(_{(6)}=3.37, p=0.003\right.$, post hoc paired $t$ test).

In Study 3, we microperfused scopolamine alone in the $\mathrm{SubC}_{\mathrm{D} / \mathrm{A}}$ at the concentration shown to be effective in Study 1 (1 $\mathrm{mM}$ ). REM sleep amount was not significantly affected compared with ACSF controls (Fig. $1 G$, example hypnogram; $H$, group data; nonsignificant main effect of scopolamine treatment: $F_{(1,13)}=$ $0.38, p=0.551$, two-way repeated-measures ANOVA). REM sleep bout frequency was also unaffected (Fig. $1 I$, nonsignificant main effect of scopolamine treatment: $F_{(1,13)}=1.11, p=0.311$, two-way repeated-measures ANOVA). Scopolamine microperfusion did, however, produce a modest shortening of REM sleep bout length $\left(t_{(13)}=2.70, p=0.011\right.$, post hoc paired $t$ test after identification of significant interaction between the factors of treatment and state: $F_{(2,26)}=8.44, p=0.002$, two-way repeatedmeasures ANOVA). These data suggest that $\mathrm{SubC}_{\mathrm{D} / \mathrm{A}}$ cholinergic neurotransmission is unnecessary for REM sleep generation.

Although the results of Study 3 indicate that cholinergic neurotransmission in the $\mathrm{SubC}_{\mathrm{D} / \mathrm{A}}$ is not substantially involved in triggering transitions into REM sleep, an analysis of NREM-toREM sleep transition dynamics shows that cholinergic input may perform a minor function in the reinforcement of transitions into REM sleep. Figure $2 \mathrm{~A}$ shows a schematic of the workflow used to standardize determination of the transition boundaries of the NREM and REM sleep clusters. Figure $2 B$ shows the state-space trajectories of successful NREM-to-REM sleep transitions from a single representative animal; each individual plotted line, projecting from NREM-to-REM sleep transition boundaries, is the state-space trajectory of a successful NREM-to-REM sleep transition. Figure $2 C$ (example) and $D$ (group data) shows that scopolamine microperfusion in the $\mathrm{SubC}_{\mathrm{D} / \mathrm{A}}$ increased NREMto-REM sleep transition duration (significant main effect of treatment: $F_{(1,13)}=35.14, p<0.001$, one-way repeated-measures ANOVA).

We also determined NREM-to-REM sleep transition duration using state acceleration plots. Although electroencephalographic state is constantly changing (i.e., state velocity is always $>0$ ), Figure $2 E$ shows that, before transitions from NREM-to-REM sleep, state velocity is nearly constant on average (i.e., mean state acceleration $\approx 0$ ). However, NREM-to-REM sleep transitions are marked by significant increases in state acceleration. Here we define transition onset as the recording epoch where the 95\% CIs of the acceleration versus time plot and the pretransition acceleration mean first separate (i.e., acceleration phase). The time point when these confidence intervals first overlap again after a subsequent deceleration phase denotes transition completion. Comparison of the acceleration versus time plots for control and scopolamine microperfusion conditions shows that, as with the analysis of state-space trajectories, blocking cholinergic neurotransmission in the $\mathrm{SubC}_{\mathrm{D} / \mathrm{A}}$ prolonged NREM-to-REM sleep transitions (in this case by $\sim 20 \mathrm{~s}$ ). It is possible that the apparent decrease in mean REM sleep bout length following scopolamine microperfusion was the result of increased NREM-to-REM sleep transition duration.

Figure $2 F$ shows the state-space trajectories of attempted NREM-to-REM sleep transitions recorded during ACSF microperfusion in a single representative animal. Unlike the successful transition trajectories shown in Figure 2B, these trajectories fail to cross the REM sleep transition boundary and instead recoil into waking or NREM state-space. Figure $2 G$ (example), $H$ (group data) shows that scopolamine microperfusion in the $\mathrm{SubC}_{\mathrm{D} / \mathrm{A}}$ increased the number of failed transitions and therefore reduced the efficiency of REM sleep initiation (significant main effect of treatment: $F_{(1,13)}=6.03, p<0.029$, one-way repeated-measures ANOVA).

Cholinergic neurotransmission in the $\mathrm{SubC}_{\mathrm{D} / \mathrm{A}}$ also functions to reinforce the electroencephalographic changes that occur in REM sleep. Figure $3 A$ shows an example EEG spectrogram containing NREM and REM sleep segments. Moving from NREMto-REM sleep, relative spectral power in the EEG shifts from the $\delta$ frequency band (i.e., $1-4 \mathrm{~Hz}$ ) toward the $\theta$ band, particularly the $7-9 \mathrm{~Hz}$ range. Figure $3 B$ shows that, during scopolamine microperfusion in the $\mathrm{SubC}_{\mathrm{D} / \mathrm{A}}$, this shift in relative power is attenuated relative to control. Group data in Figure $3 C-E$ show that, in REM sleep, microperfusion of scopolamine into the $\mathrm{SubC}_{\mathrm{D} / \mathrm{A}}$ sig- 


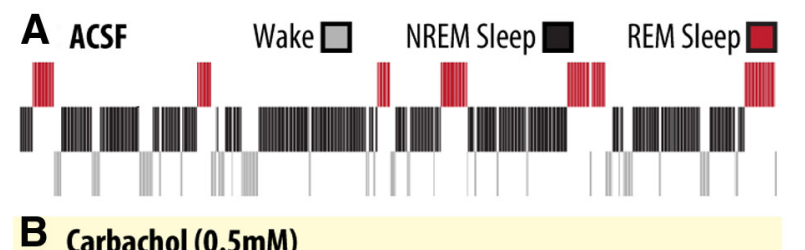

\section{B Carbachol $(0.5 \mathrm{mM})$}

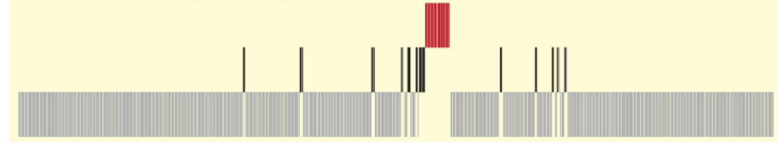

D Carbachol + Scopolamine (1mm)

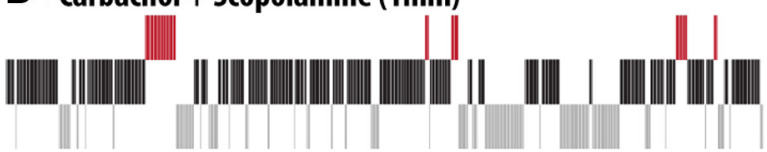

E D-AP5 $(200 \mu M)+$ Muscimol $(10 \mu M)$

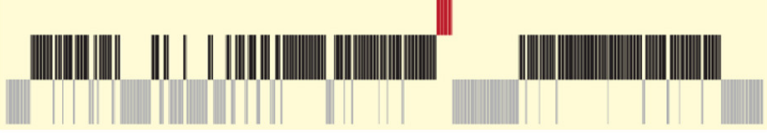

\section{G Scopolamine $(1 \mathrm{mM})$}
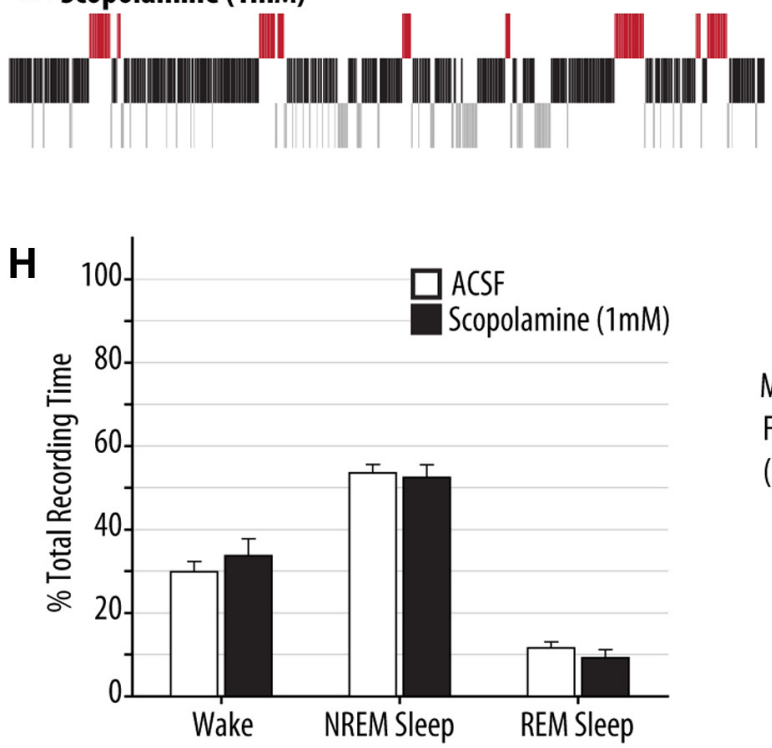
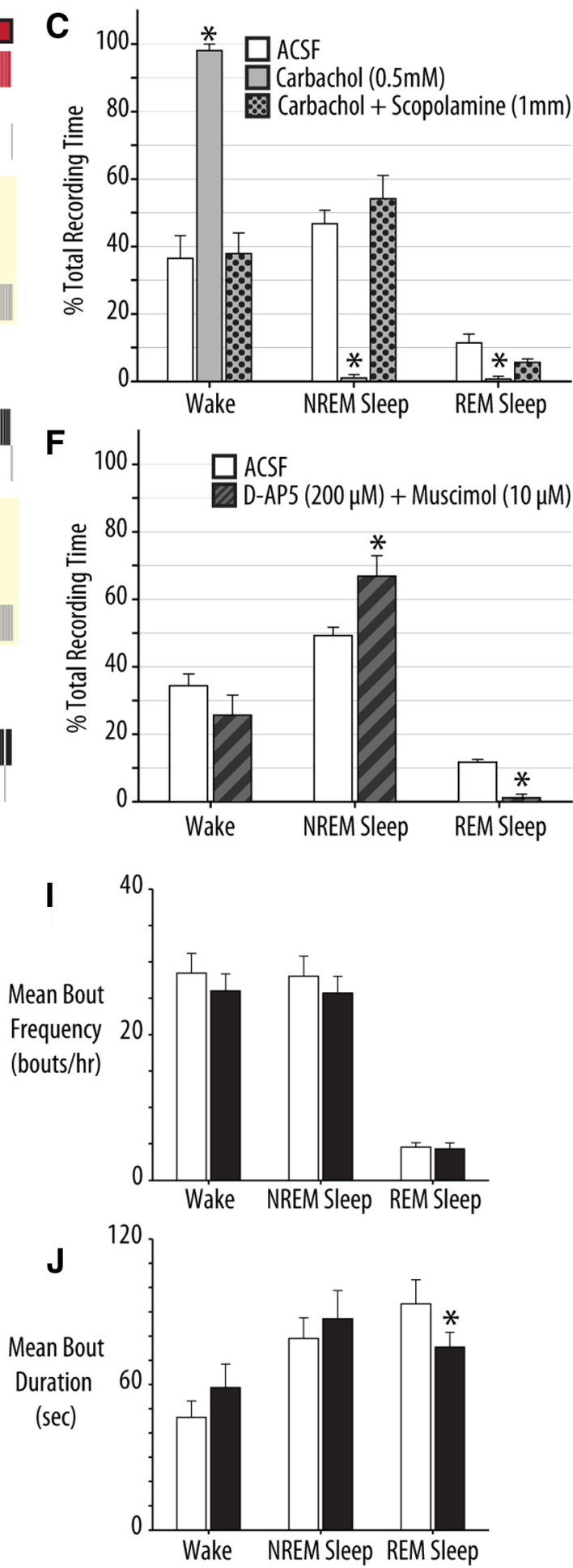

Figure 1. Cholinergic input to the $\mathrm{SubC}_{\mathrm{D} / \mathrm{A}}$ is not necessary for REM sleep generation. Example hyponograms and group data showing the effects of drug microperfusion into the $S_{\text {ub }} \mathrm{C}_{\mathrm{D} / \mathrm{A}}$ on sleep architecture from Studies 1-3. All hypnograms show representative sleep architecture over $1 \mathrm{~h}$ periods. $\boldsymbol{A}-\boldsymbol{D}$, Results of Study $1(n=4)$ : carbachol (cholinergic receptor agonist; $0.5 \mathrm{~mm})$ and carbachol combined with scopolamine (muscarinic receptor antagonist; $1 \mathrm{mM}$ ). $\boldsymbol{E}, \boldsymbol{F}$, Results of Study 2 ( $n=6$ ): combined microperfusion of D-AP5 (NMDA receptor antagonist; $1 \mathrm{~mm}$ ) and muscimol $\left(G_{A B A}\right.$ receptor agonist; $\left.10 \mu \mathrm{M}\right) . \mathbf{G}-J$, Results of Study $3(n=14)$ : microperfusion of scopolamine alone $(1 \mathrm{~mm})$. Values are mean \pm SEM. ${ }^{*} p<0.05$, significant differences compared with the respective ACSF control (paired $t$ test).

nificantly increased relative power in the $1-3,3-5$, and $9-11 \mathrm{~Hz}$ frequency ranges, whereas relative power in the $7-9 \mathrm{~Hz}$ range decreased significantly (range of $t_{(13)}=7.11-1.40$, range of $p<$ 0.001 to $p=0.042$, post hoc paired $t$ tests after identification of significant interaction between the factors treatment and fre- quency band: $F_{(15,195)}=4.60, p<0.001$, two-way repeatedmeasures ANOVA). This EEG effect is also evident in the example state space plots shown in Figure $2 B, C$, where in the scopolamine condition the combination of increased $\delta$ power and reduced $\theta$ power in REM sleep is responsible for the downward-rightward 


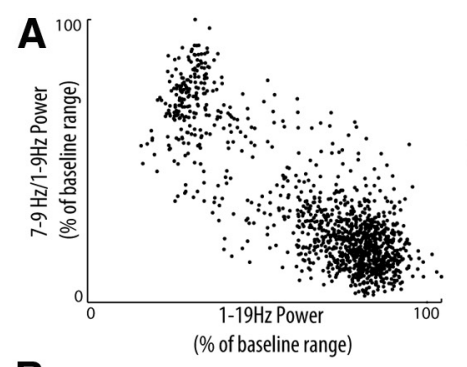

\section{B}
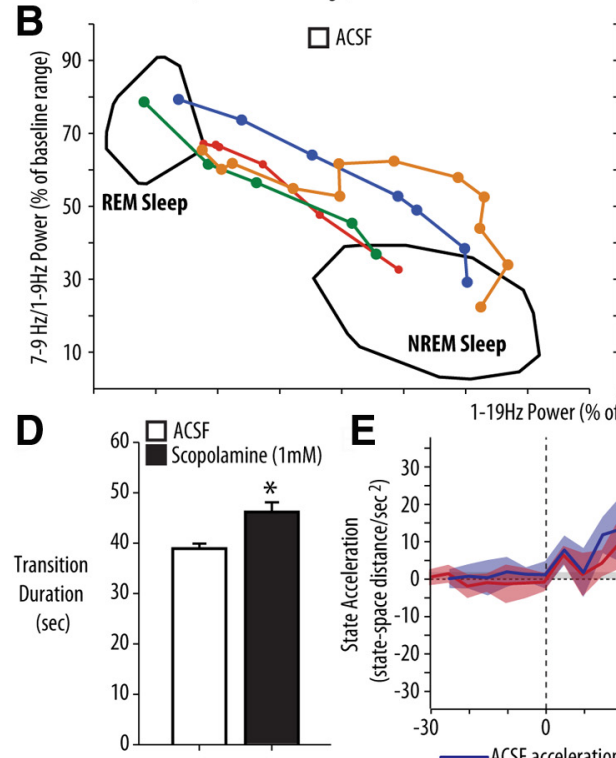

E

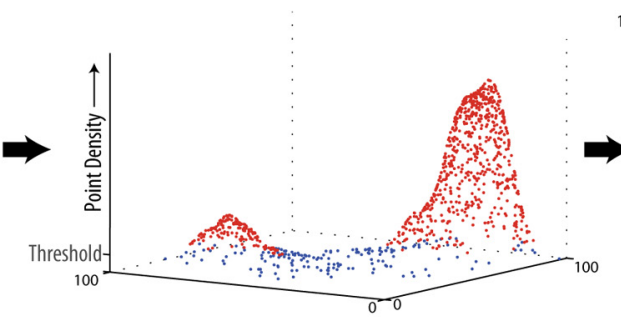

C

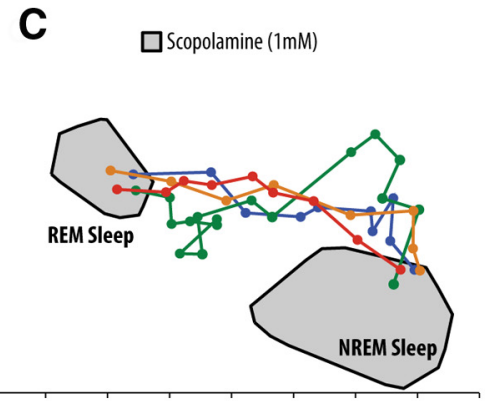

$1-19 \mathrm{~Hz}$ Power (\% of baseline range)

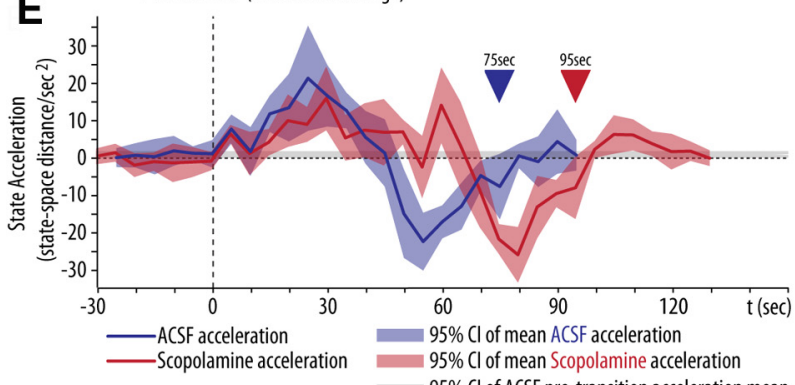

$\mathbf{F}$



G

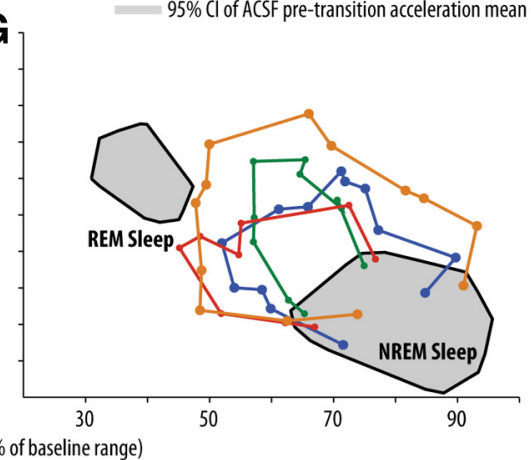

H

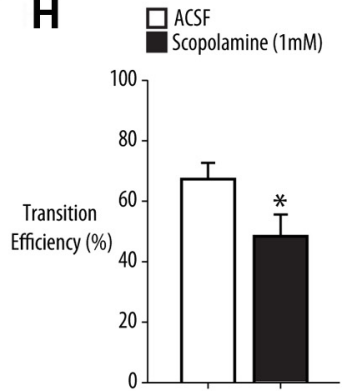

Figure 2. Cholinergic input to the $\mathrm{SubC}_{\mathrm{D} / \mathrm{A}}$ increases the reliability of REM sleep generation. Shown are the results of a state-space based analysis of NREM-to-REM sleep transition dynamics. $A$, A schematic of the workflow used to standardize determination of the transition boundaries of the non-REM and REM sleep clusters. Left, An example state-space plot from the ACSF condition of a single rat showing the positions of NREM and REM sleep epochs. Middle, Local point densities derived using Voronoi tessellation. Right, Location of the NREM and REM sleep transition boundaries obtained by applying a density threshold and fitting individual convex envelopes to each of the two high-density clusters. B, C, Example trajectories of NREM-to-REM sleep transitions in conditions of ACSF and scopolamine microperfusion into the $\mathrm{SubC}_{\mathrm{D} / \mathrm{A}}$, respectively. Each plotted line projecting from NREM-to-REM sleep transition boundaries is the state-space trajectory of a successful NREM-to-REM sleep transition. $\boldsymbol{D}$, Group data showing the effect of scopolamine microperfusion into the $\mathrm{SubC}_{\mathrm{D} / \mathrm{A}}$ on the duration of successful NREM-to REM sleep transitions. $\boldsymbol{E}_{\text {, Mean state }}$ acceleration across NREM-to-REM sleep transitions in ACSF and scopolamine microperfusion conditions. Transition onset is normally marked by the beginning of an acceleration phase (separation of the $95 \% \mathrm{Cl}$ of the acceleration mean from that of the pretransition acceleration mean). Transition termination is marked by the end of a subsequent deceleration phase. $\boldsymbol{F}, \mathbf{G}$, Example trajectories of failed NREM-to-REM sleep transitions in ACSF and scopolamine microperfusion conditions. $\boldsymbol{H}$, Group data showing the effect of scopolamine microperfusion into the SubC $C_{D / A}$ on the NREM-to-REM sleep transition efficiency: (no. of successful transitions)/(sum of successful and failed transitions). NREM-to REM sleep transition plots are representative of $1 \mathrm{~h}$ of recording. $\boldsymbol{D}, \boldsymbol{H}$, Values are mean \pm SEM. ${ }^{*} p<0.05$, significant differences compared with the respective ACSF control (paired $t$ test).

shift of the REM cluster toward the NREM sleep cluster. In Figure $3 F$, we plotted the difference of the NREM and REM sleep relative power spectra, which shows the REM sleep-specific effects of scopolamine microperfusion on EEG power. This analysis shows that the major EEG change occurring in REM sleep (increased relative power in the $7-9 \mathrm{~Hz}$ range) was significantly attenuated by microperfusion of scopolamine into the $\mathrm{SubC}_{\mathrm{D} / \mathrm{A}}(27 \%$ reduction, $t_{(13)}=7.86, p<0.001$, post hoc paired $t$ test after identifica- tion of significant interaction between the factors treatment and frequency band: $F_{(15,195)}=5.06, p<0.001$, two-way repeatedmeasures ANOVA). Also, the normal suppression of relative power in the $9-11 \mathrm{~Hz}$ band occurring in REM sleep compared with NREM sleep was also modestly attenuated $\left(t_{(13)}=2.35, p<\right.$ 0.020 , post hoc paired $t$ test). Postural muscle tone in REM sleep was unaffected by scopolamine microperfusion in the $\mathrm{SubC}_{\mathrm{D} / \mathrm{A}}$ relative to ACSF controls (ACSF control $0.740 \pm 0.291$ arbitrary 

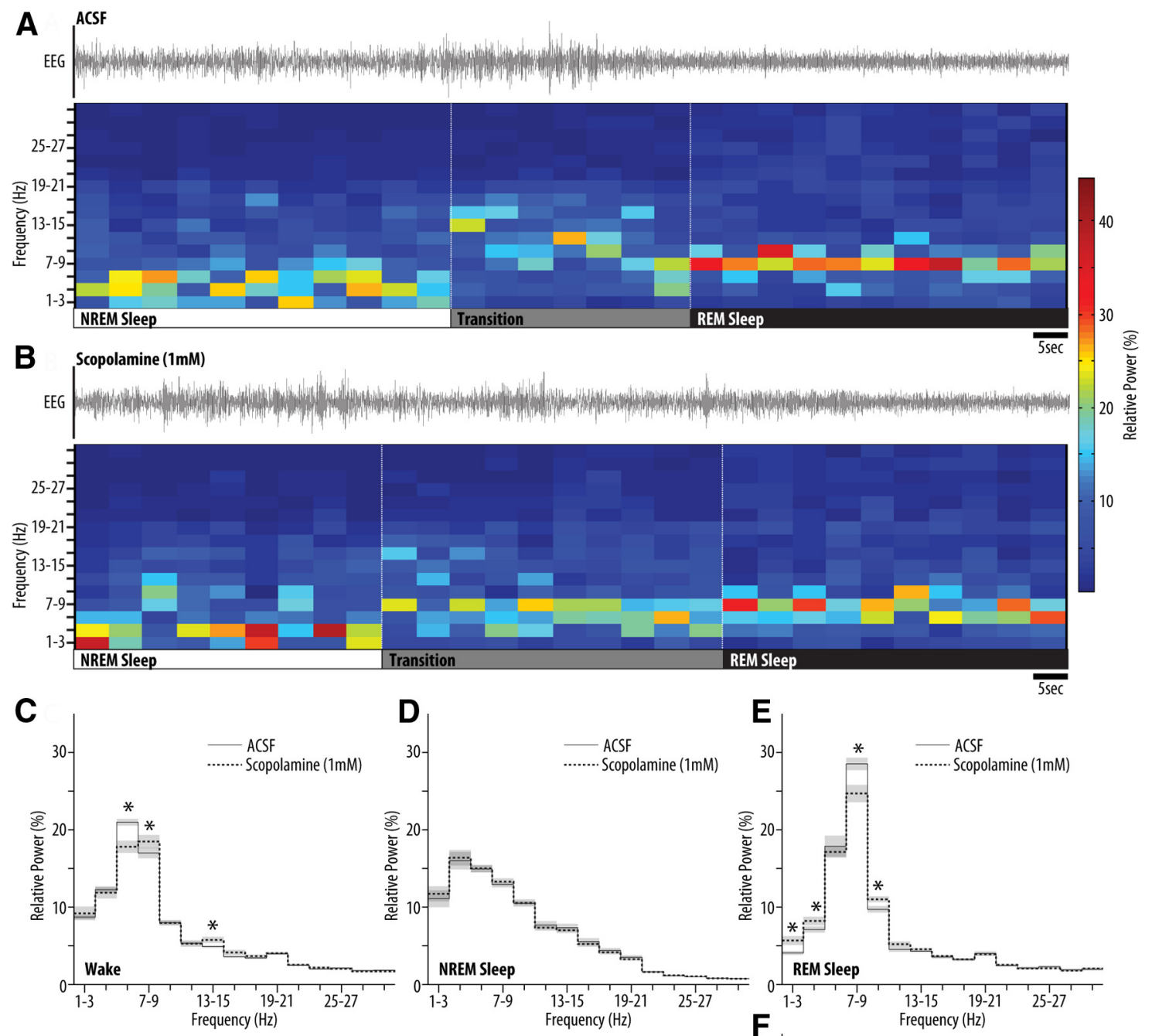

$\mathbf{E}$
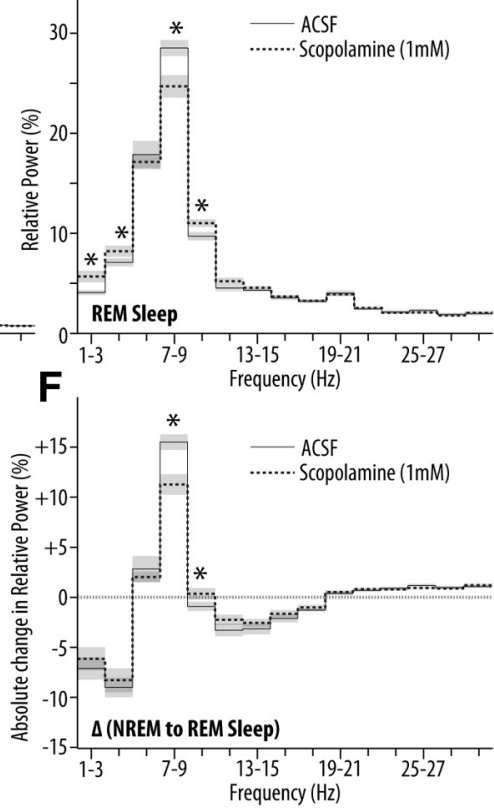

Figure 3. Cholinergic input to the $S u b C_{D / A}$ reinforces the activation of $\theta$ oscillations in REM sleep. Example spectrograms and group data showing the effects of scopolamine microperfusion into the $\mathrm{SubC}_{\mathrm{D} / \mathrm{A}}$ on electroencephalographic activity across sleep-wake states. $\boldsymbol{A}, \boldsymbol{B}$, Representative EEG tracings across NREM-to-REM sleep transitions and their corresponding spectrograms taken from ACSF and scopolamine microperfusion conditions, respectively. Transition boundaries (vertical dotted lines) were defined using the state-space method described in Figure $2 A$. $C-\boldsymbol{E}$, Group data showing the effects of scopolamine versus ACSF microperfusion on relative EEG power distributions in wakefulness, NREM sleep, and REM sleep, respectively. $\boldsymbol{F}$, Group data showing the absolute changes in relative EEG power in REM sleep with respect to NREM sleep (i.e., the REM sleep-specific effects of scopolamine microperfusion on electroencephalographic activity). Values are mean \pm SEM (indicated by gray bands). ${ }^{*} p<0.05$, significant differences compared with the respective ACSF control (paired $t$ test).

units versus scopolamine $0.741 \pm 0.304$; nonsignificant main effect of treatment: $F_{(1,13)}=0.0018, p=0.097$, one-way repeatedmeasures ANOVA).

Together, the above results suggest that cholinergic neurotransmission in the $\mathrm{SubC}_{\mathrm{D} / \mathrm{A}}$ is not a major determinant of REM sleep quantity or frequency; rather, cholinergic input functions in a minor role to reinforce both the transitioning into, and the electroencephalographic features of, REM sleep. We hypothesized that these findings can be explained by a mutually excitatory interaction between the $\mathrm{SubC}_{\mathrm{D} / \mathrm{A}}$ and the cholinergic PPT/
LDT where, importantly, cholinergic neuron activation is gated by SubC $_{\mathrm{D} / \mathrm{A}}$ activity. We used simulations of a model REM sleep circuit to test the plausibility of this hypothesis (for circuit wiring diagram, see Fig. 4A; for a detailed rationale, refer to Materials and Methods). We mimicked in vivo muscarinic receptor antagonism by varying the weight of synaptic input from the "PPT/ LDT" pool to the "SubC $\mathrm{D} / \mathrm{A}$ " pool.

Figure $4 B$ shows normalized " $\mathrm{SubC}_{\mathrm{D} / \mathrm{A}}$ " firing frequency versus time plots for different levels of cholinergic input to the "SubC $\mathrm{D} / \mathrm{A}_{\mathrm{A}}$." Importantly, reducing or removing cholinergic pos- 

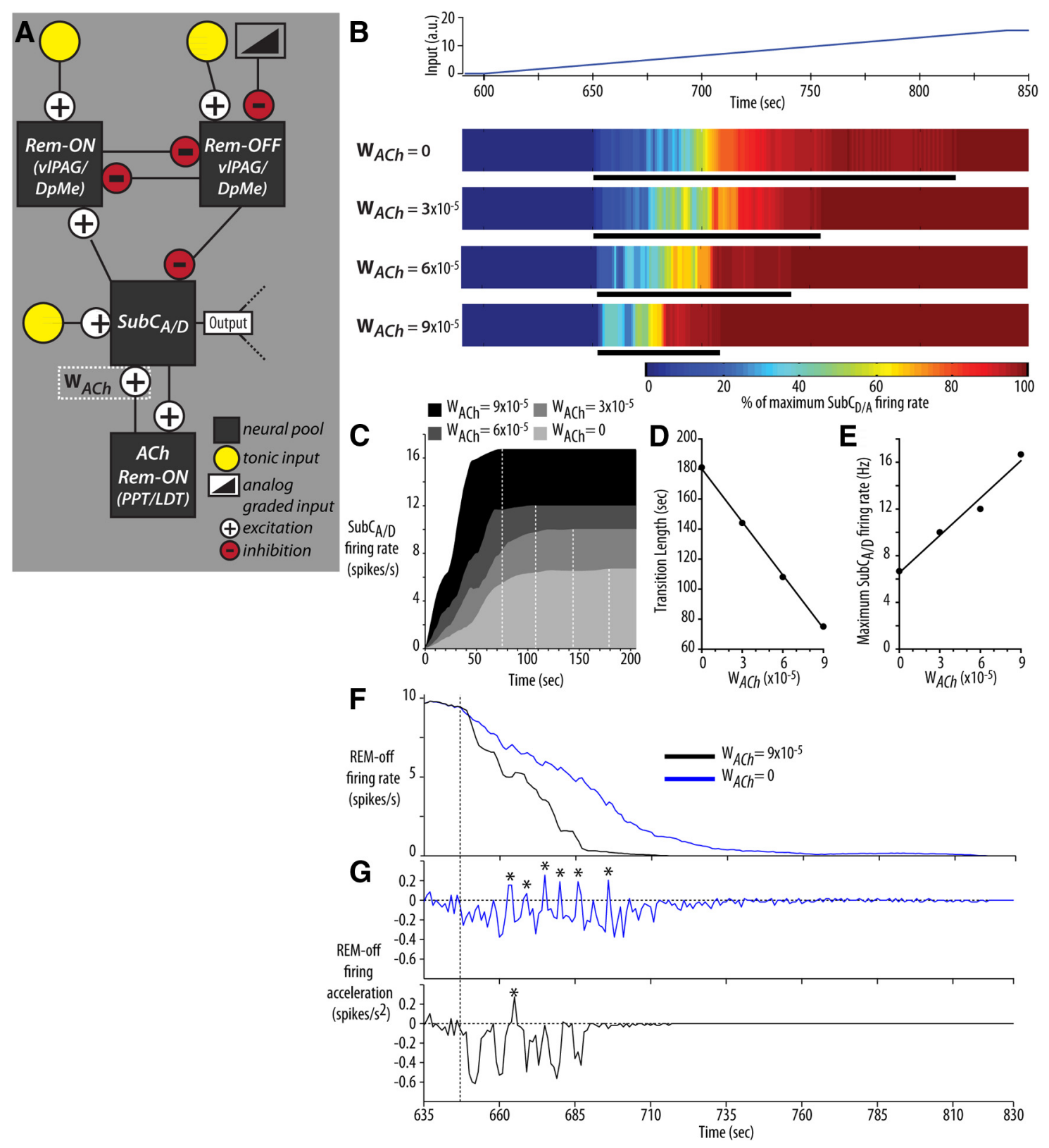

Figure 4. In vivo effects of $S_{u b C}$ cholinergic receptor blockade can be replicated in silico when cholinergic input to the $S_{u b C}$ D/A operates as positive feedback. $A$, Wiring diagram of the modeled circuit (the rationale for its topology is detailed in Materials and Methods). $\boldsymbol{B}$, Normalized (\% of maximum) firing frequency versus time plots for model neurons in the SubC $\mathrm{D}_{\mathrm{A}}$ pool for different weights of the cholinergic PPT/LDT pool input (i.e., $W_{A C h}$ ). $C$, Absolute firing frequency versus time for $S_{\text {ub }} C_{D / A}$ pool neurons at different values of $W_{A C h}$. Time 0 equals transition onset; white dotted lines indicate transition endpoints. $\boldsymbol{D}, \boldsymbol{E}$, The effect of varying $\mathrm{W}_{\mathrm{ACh}}$ on transition length and maximum SubC $C_{D / A}$ firing rate, respectively. $\boldsymbol{F}$, Absolute firing frequency versus time plots for model neurons in the REM-off pool for maximum and inactive $W_{A C h}$. The black dotted line indicates the onset of inhibitory graded input to the REM-off pool. G, Firing acceleration in the REM-off pool for maximum and inactive $\mathrm{W}_{\mathrm{ACh}}{ }^{*}$ The occurrence of an acceleration in REM-off neuronal firing. All firing rate data were smoothed by moving average.

itive feedback to the "SubC $C_{\mathrm{D} / \mathrm{A}}$ " pool did not delay transition onset and therefore did not affect the activation threshold of the $\mathrm{SubC}_{\mathrm{D} / \mathrm{A}}$ pool, likely a major determinant of REM sleep quantity in vivo. Nevertheless, reducing cholinergic input to the "SubC $\mathrm{D}_{\mathrm{D} / \mathrm{A}}$ " pool resulted in transition lengthening and suppression of peak "SubC $\mathrm{D} / \mathrm{A}$ " pool firing rates (Fig. $4 B-E$ ). In vivo, blockade of muscarinic neurotransmission in the $\mathrm{SubC}_{\mathrm{D} / \mathrm{A}}$ likewise increased NREM-to-REM sleep transition duration without a concomitant reduction in REM quantity. Figure $4 F, G$ shows REM-off pool firing frequency and acceleration during the "NREM-to-REM sleep" transition. In the absence of cholinergic positive feedback $\left(\mathrm{W}_{A C H}=0\right)$, the activity of the mutually inhibitory feedback loop produced al- ternating periods of firing deceleration and acceleration in the REM-off pool. Transitions are ultimately successful because deceleration amplitude exceeds acceleration amplitude ensuring eventual inactivation of the REM-off pool. Although our simple model circuit is not capable of producing failed transitions, accelerations in REM-off (i.e., GABAergic REMinactive vlPAG/DpMe) neuron firing is a plausible source of the transition failure occurring in vivo. Therefore, of relevance to our in vivo finding that NREM-to-REM transitions failed less often when muscarinic neurotransmission in the $\mathrm{SubC}_{\mathrm{D} / \mathrm{A}}$ was intact, the addition of cholinergic positive feedback into the $\mathrm{SubC}_{\mathrm{D} / \mathrm{A}}$ potentiated REM-off decelerations while reducing the frequency of accelerations. 
Our findings can be taken to suggest that cholinergic input to the $\mathrm{SubC}_{\mathrm{D} / \mathrm{A}}$ may play a minor modulatory role in REM sleep generation: reinforcing transitions into REM sleep through a potential positive feedback interaction between the $\mathrm{SubC}_{\mathrm{D} / \mathrm{A}}$ and the PPT/LDT. If this interpretation is valid, we would expect selective activation of PPT/LDT cholinergic neurons to produce a reinforcement of REM sleep transitioning that contrasts the effects of cholinergic receptor antagonism in the $\mathrm{SubC}_{\mathrm{D} / \mathrm{A}}$. To selectively activate cholinergic cells in the PPT, we used microperfusion of urotensin-II (4 pM). Consistent with a previous report (Huitron-Resendiz et al., 2005), Figure $5 A, B$ shows that microperfusion of urotensin-II in the PPT enhanced REM sleep through an increase in mean bout frequency $\left(t_{(6)}=4.85\right.$ and 6.26, $p=0.009$ and $p<0.001$, respectively, post hoc paired $t$ tests after identification of significant main effect of treatment $F_{(1,6)}=14.61$ and 28.51 , respectively, all $p<0.001$, one-way repeated-measures ANOVA). Opposite the effects of cholinergic receptor antagonism in the $\mathrm{SubC}_{\mathrm{D} / \mathrm{A}}$, Figure $5 C, D$ shows that urotensin-II microperfusion in the PPT increased NREM-to-REM sleep transition efficiency and reduced transition length $t_{(6)}=4.85$ and 1.56, $p=0.001$ and $p=0.437$, respectively, post hoc paired $t$ tests after identification of significant main effect of treatment: $F_{(1,6)}=29.03$ and 20.98, respectively, all $p<0.001$, one-way repeated-measures ANOVA). Importantly, Figure $5 A-D$ also shows that the effects of activating cholinergic PPT neurons with urotensin-II were blocked by simultaneous antagonism of muscarinic acetylcholine receptors in the $\operatorname{SubC}_{\mathrm{D} / \mathrm{A}}$.

Figure 6 shows the location of the microperfusion sites from all experiments in Studies 1-4. Figure 6A, $B$ shows that that all microdialysis probes targeted to the SubC are located within the dorsal and $\alpha$ parts as defined by Paxinos and Watson (1998). Figure $6 C$ shows an example microperfusion lesion located adjacent to NADPH-diaphorase positive cholinergic PPT neurons (i.e., darkly stained cluster of cell bodies). Figure $6 D$ shows the location of all the PPT microperfusion sites from experiments in Studies 4 . The sites of microperfusion are within or adjacent to the PPT in all rats.

\section{Discussion}

If cholinergic input to the $\mathrm{SubC}_{\mathrm{D} / \mathrm{A}}$ were critically involved in the generation of REM sleep, we would expect antagonism of $\mathrm{SubC}_{\mathrm{D} / \mathrm{A}}$ acetylcholine receptors to reduce REM sleep amounts. However, here we show that local antagonism of $\mathrm{SubC}_{\mathrm{D} / \mathrm{A}}$ muscarinic acetylcholine receptors did not suppress REM sleep quantity or bout frequency. Because the same concentration of scopolamine was sufficient to block the effects of exogenous cholinergic stimulation $\left(\mathrm{SubC}_{\mathrm{D} / \mathrm{A}}\right.$ carbachol delivery and activation of PPT cholinergic cells), we expect that endogenous cholinergic input to the $\mathrm{SubC}_{\mathrm{D} / \mathrm{A}}$ was effectively inhibited. Therefore, our data suggest that REM sleep drives to the $\mathrm{SubC}_{\mathrm{D} / \mathrm{A}}$ are acetylcho- line independent (i.e., cholinergic input to the $\mathrm{SubC}_{\mathrm{D} / \mathrm{A}}$ is not necessary for REM sleep generation).

Our data are consistent with previous preliminary studies reporting the effects of $\mathrm{SubC}_{\mathrm{D} / \mathrm{A}}$ cholinergic receptor antagonism. George et al. (1964), in their seminal study of carbachol-induced REM sleep, reported that, whereas pontine microinjections of either carbachol or oxotremorine (a muscarinic agonist) induced atropine-sensitive REM sleep, atropine alone had no "visible effects." However, atropine was focally delivered in only two cats, and no data were shown. Similar studies in rats by Gnadt and Pegram (1986; $n=5)$ and Bourgin et al. $(1995 ; n=3$, data not shown in their study) reported no effects on REM sleep of pontine atropine microinjections at doses sufficient to prevent the wake and REM sleep-inducing effects of carbachol.

Conversely, two studies have reported REM sleep reductions following infusions of cholinergic receptor antagonists. First, Shiromani and Fishbein (1986) reported significant reductions of REM sleep following pontine infusions of scopolamine. However, infusions took place continuously over $5 \mathrm{~d}$ using a chronically implanted mini-pump. In this case, scopolamine delivery was therefore more akin to wide-reaching systemic administration and not indicative of blocking muscarinic neurotransmission in the pontine reticular formation per se. Second, Imeri et al. (1994) reported reductions in REM sleep following pontine microinjections of methoctramine, a muscarinic receptor antagonist; however, reduced REM sleep may have been a secondary effect of arousal because NREM sleep time was also reduced while wakefulness increased.

Past models of cholinergic involvement in REM sleep generation (e.g., the reciprocal interaction hypothesis) claim that cholinergic input facilitates the initial activation of the $\mathrm{SubC}_{\mathrm{D} / \mathrm{A}}$ (Pace-Schott and Hobson, 2002). If this were the case, blockade 


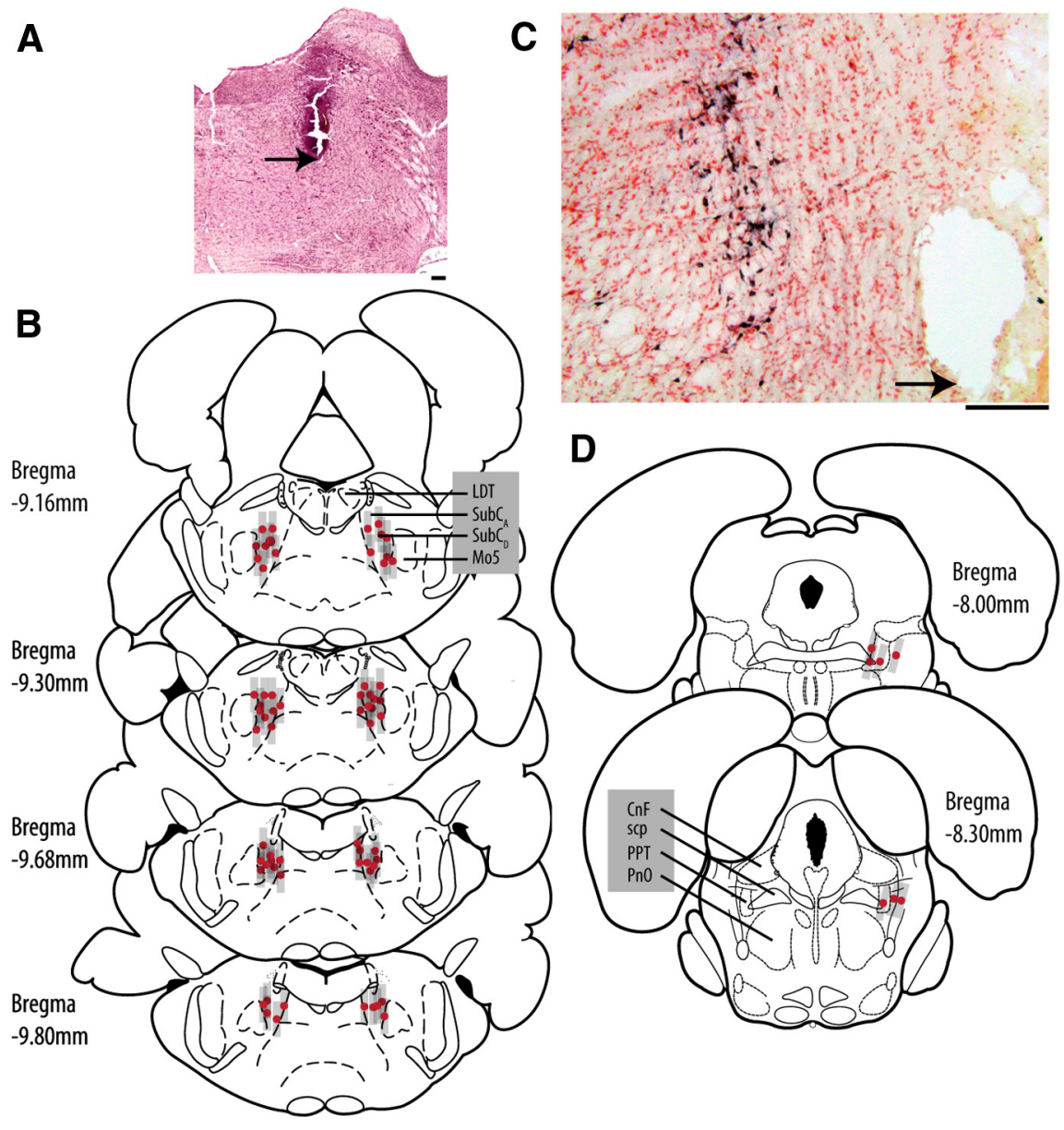

Figure 6. Example $(\boldsymbol{A})$ and group data $(\boldsymbol{B})$ showing the location of all the $\mathrm{SubC}_{\mathrm{D} / \mathrm{A}}$ microperfusion sites from all experiments in Studies 1-4. C, Example microperfusion lesion located adjacent to NADPH-diaphorase-positive cholinergic PPT neurons (i.e., darkly stained cluster of cell bodies). $\boldsymbol{D}$, Group data showing the location of all the PPT microperfusion sites from experiments in Study 4. $\boldsymbol{A}, \boldsymbol{C}$, Arrows indicate the location of microperfusion lesion sites. $\boldsymbol{B}, \boldsymbol{D}$, Red circles represent the midpoint positions of the permeable membrane portion of the microdialysis probes; surrounding gray boxes represent scale representations of the position of the entire membranes. Scale bars, $100 \mu \mathrm{m}$. Mo5, Trigeminal motor pool; CnF, cuneiform nucleus; scp, superior cerebellar peduncle; $\mathrm{PnO}$, oral part of the pontine reticular nucleus.

of cholinergic input to the $\mathrm{SubC}_{\mathrm{D} / \mathrm{A}}$ would have the effect of increasing the activation threshold for REM sleep (i.e., increased levels of GABAergic disinhibition and/or glutamatergic excitation would be needed to initially activate the $\mathrm{SubC}_{\mathrm{D} / \mathrm{A}}$ and initiate a NREM-to-REM sleep transition). However, our finding that REM sleep amount and bout frequency were unaffected by blockade of muscarinic neurotransmission does not support this mechanism because we would predict less REM sleep and/or reduced bout frequency when increasing the activation threshold for REM sleep. Therefore, contrary to some previous models, our data suggest that cholinergic input is not a major source of extrinsic facilitatory drive to REM sleep-generating circuitry.

Importantly, our data indicate that cholinergic input may serve a minor function in the reinforcement of transitions into REM sleep following their initial initiation. First, our analysis of NREM-to-REM sleep transition dynamics revealed that blocking muscarinic neurotransmission in the $\mathrm{SubC}_{\mathrm{D} / \mathrm{A}}$ modestly increased both the duration and failure rate of transitions into REM sleep. Second, our findings show that cholinergic PPT neurons, a major source of cholinergic input to the $\mathrm{SubC}_{\mathrm{D} / \mathrm{A}}$, are capable of reinforcing NREM-to-REM sleep transitioning through the $\mathrm{SubC}_{\mathrm{D} / \mathrm{A}}$. Selective activation of PPT cholinergic neurons with
urotensin-II decreased the duration and failure rate of transitions into REM sleep, and these effects were blocked by cholinergic receptor antagonism in the $\mathrm{SubC}_{\mathrm{D} / \mathrm{A}}$. We showed using computational modeling that our in vivo results are consistent with their being a mutually excitatory interaction between the "SubC $\mathrm{D} / \mathrm{A}_{\text {" }}$ and "PPT/LDT" pools where, importantly, cholinergic neuron activation is gated by "SubC $\mathrm{D}_{\mathrm{A} / \mathrm{A}}$ " activity. Modeling showed that with this sequence of activation, reducing or eliminating "PPT/LDT" input to the "SubC $\mathrm{D}_{\mathrm{A} / \mathrm{A}}$ " pool did not affect the activation threshold of "REM sleep" (i.e., time of transition onset for the " $\mathrm{SubC}_{\mathrm{D} / \mathrm{A}}$ " pool was unchanged). However, following transition onset, positive feedback from the "PPT/ LDT" pool accelerated firing in the "SubC $\mathrm{D}_{\mathrm{D} / \mathrm{A}}$ " pool and reduced "NREM-toREM sleep" transition duration.

Our in vivo data also show that cholinergic input to the $\mathrm{SubC}_{\mathrm{D} / \mathrm{A}}$ normally acts to protect against the failure of NREM-toREM sleep transitions. Simulations showed that cholinergic input in the form of positive feedback could function to dampen potentially destabilizing surges in REM-off neuron activity that might cause transition failure in vivo. This type of positive feedback is a common feature of biological switches and has been shown to increase switch reliability, making them resistant to extrinsic noise and rapidly inducible (Brandman et al., 2005; Brandman and Meyer, 2008).

Antagonism of muscarinic neurotransmission in the $\mathrm{SubC}_{\mathrm{D} / \mathrm{A}}$ attenuated the increase in relative EEG $\theta$ power that characterizes REM sleep. Hippocampal $\theta$ oscillations are produced by septohippocampal projections (Gerashchenko et al., 2001). The SubC contains glutamatergic neurons projecting to the medial septum and lesioning these $\mathrm{SubC}_{\mathrm{A}}$ cells eliminates $\theta$ oscillations during REM sleep (Lu et al., 2006). Therefore, our data would indicate that cholinergic input to the $\mathrm{SubC}_{\mathrm{D} / \mathrm{A}}$ contributes to the generation of $\theta$ oscillations in REM sleep through facilitation of a $\mathrm{SubC}_{\mathrm{D} / \mathrm{A}}$-septum-hippocampus pathway. Simulations showed that "cholinergic" positive feedback into the "SubC $\mathrm{A}_{\mathrm{A}}$ " pool produces amplification of "SubC $\mathrm{D}_{\mathrm{D} / \mathrm{A}}$ " firing, which could underlie reinforcement of $\theta$ oscillations by $\mathrm{SubC}_{\mathrm{D} / \mathrm{A}}$ acetylcholine in vivo. Conversely, despite evidence that carbachol activates spinally projecting $\mathrm{SubC}_{\mathrm{D} / \mathrm{A}}$ neurons via presynaptic and postsynaptic muscarinic mechanisms in vitro (Weng et al., 2014), we observed no reduction in motor atonia during REM sleep following antagonism of $\mathrm{SubC}_{\mathrm{D} / \mathrm{A}}$ muscarinic neurotransmission.

A positive feedback mechanism can account for why modulating endogenous $\mathrm{SubC}_{\mathrm{D} / \mathrm{A}}$ acetylcholine has little effect on REM sleep whereas exogenous cholinergic stimulation can potently induce REM sleep. Our own data show that exogenously activating cholinergic PPT input to the $\mathrm{SubC}_{\mathrm{D} / \mathrm{A}}$ increased REM sleep; however, cholinergic receptor antagonism at the $\mathrm{SubC}_{\mathrm{D} / \mathrm{A}}$ did not decrease REM sleep amounts below baseline levels. Exogenous 
cholinergic stimulation of the $\mathrm{SubC}_{\mathrm{D} / \mathrm{A}}$ effectively mimics the action of an extrinsic facilitatory drive. However, in the event that endogenous cholinergic input provides positive feedback, the effects of exogenous stimulation would not be indicative of the normal function of $\mathrm{SubC}_{\mathrm{D} / \mathrm{A}}$ cholinergic inputs. In this case, exogenous stimulation would unphysiologically reverse the normal sequence of $\mathrm{SubC}_{\mathrm{D} / \mathrm{A}}$ and cholinergic neuron activity. Therefore, in the case that cholinergic input is providing a positive feedback to the $\mathrm{SubC}_{\mathrm{D} / \mathrm{A}}$, cholinergic receptor antagonism could have little or no effect on REM sleep quantity despite there being a major capacity for exogenous cholinergic stimulation to initiate REM sleep or its component parts.

Although cholinergic agonism of the $\mathrm{SubC}_{\mathrm{D} / \mathrm{A}}$ can trigger REM sleep, it also induces prolonged bouts of wakefulness characterized by abnormal motor behavior in both cats (Mitler and Dement, 1974; van Dongen, 1980; Baghdoyan et al., 1984b) and rodents (Gnadt and Pegram, 1986; Mastrangelo et al., 1994; Deurveilher et al., 1997). Consistent with previous rodent studies, the major effect of carbachol delivery in our study was induction of wakefulness. We hypothesized that the induction of wakefulness was an epiphenomenon of motor activation. REM sleep-generating neurons in $\mathrm{SubC}_{\mathrm{D} / \mathrm{A}}$ overlap with pools of cholinoceptive reticulospinal cells that facilitate muscle activity and locomotion (Lai and Siegel, 1991). These pools are innervated by the mesencephalic locomotory region, stimulation of which produces motor activity like that seen in this and other studies (i.e., hyperactive circling, forceful kicking of the hind limbs, explosive jumping, and freezing) (Depoortere et al., 1990). Importantly, we confirmed that we had effectively targeted REM sleep circuitry and that we could predictably modulate REM sleep generation by avoiding the confounding activation of locomotion circuitry. Reticulospinal cells responsible for motor activation are driven by NMDA receptor-dependent glutamatergic inputs (Lai and Siegel, 1991). Simultaneous delivery of an NMDA receptor antagonist and a $\mathrm{GABA}_{\mathrm{A}}$ receptor agonist effectively prevented motor activation while strongly suppressing REM sleep generation. Moreover, indirect enhancement of $\mathrm{SubC}_{\mathrm{D} / \mathrm{A}}$ acetylcholine inputs through activation of cholinergic PPT neurons successfully increased REM sleep. These findings support the interpretation that wakefulness induced by direct cholinergic stimulation of the $\mathrm{SubC}_{\mathrm{D} / \mathrm{A}}$ is the result of motor activation that effectively conceals any REM sleep effects.

\section{References}

Baghdoyan HA, Rodrigo-Angulo ML, McCarley RW, Hobson JA (1984a) Site-specific enhancement and suppression of desynchronized sleep signs following cholinergic stimulation of three brainstem regions. Brain Res 306:39-52. CrossRef Medline

Baghdoyan HA, Monaco AP, Rodrigo-Angulo ML, Assens F, McCarley RW, Hobson JA (1984b) Microinjection of neostigmine into the pontine reticular formation of cats enhances desynchronized sleep signs. J Pharmacol Exp Ther 231:173-180. Medline

Boissard R, Gervasoni D, Schmidt MH, Barbagli B, Fort P, Luppi PH (2002) The rat ponto-medullary network responsible for paradoxical sleep onset and maintenance: a combined microinjection and functional neuroanatomical study. Eur J Neurosci 16:1959-1973. CrossRef Medline

Boissard R, Fort P, Gervasoni D, Barbagli B, Luppi PH (2003) Localization of the GABAergic and non-GABAergic neurons projecting to the sublaterodorsal nucleus and potentially gating paradoxical sleep onset. Eur J Neurosci 18:1627-1639. CrossRef Medline

Bourgin P, Escourrou P, Gaultier C, Adrien J (1995) Induction of rapid eye movement sleep by carbachol infusion into the pontine reticular formation in the rat. Neuroreport 6:532-536. CrossRef Medline

Brandman O, Meyer T (2008) Feedback loops shape cellular signals in space and time. Science 322:390-395. CrossRef Medline

Brandman O, Ferrell JE Jr, Li R, Meyer T (2005) Interlinked fast and slow positive feedback loops drive reliable cell decisions. Science 310:496-498. CrossRef Medline

Brunel N, van Rossum MC (2007) Lapicque's 1907 paper: from frogs to integrate-and-fire. Biol Cybern 97:337-339. CrossRef Medline

Burkitt AN (2006) A review of the integrate-and-fire neuron model: I. Homogeneous synaptic input. Biol Cybern 95:1-19. CrossRef Medline

Carli G, Zanchetti A (1965) A study of pontine lesions suppressing deep sleep in the cat. Arch Ital Biol 103:751-788. Medline

Clément O, Sapin E, Bérod A, Fort P, Luppi PH (2011) Evidence that neurons of the sublaterodorsal tegmental nucleus triggering paradoxical (REM) sleep are glutamatergic. Sleep 34:419-423. Medline

Crochet S, Onoe H, Sakai K (2006) A potent non-monoaminergic paradoxical sleep inhibitory system: a reverse microdialysis and single-unit recording study. Eur J Neurosci 24:1404-1412. CrossRef Medline

Depoortere R, Di Scala G, Sandner G (1990) Treadmill locomotion and aversive effects induced by electrical stimulation of the mesencephalic locomotor region in the rat. Brain Res Bull 25:723-727. CrossRef Medline

Deurveilher S, Hars B, Hennevin E (1997) Pontine microinjection of carbachol does not reliably enhance paradoxical sleep in rats. Sleep 20:593-607. Medline

Diniz Behn CG, Klerman EB, Mochizuki T, Lin SC, Scammell TE (2010) Abnormal sleep/wake dynamics in orexin knockout mice. Sleep 33:297306. Medline

Garzón M, De Andrés I, Reinoso-Suárez F (1998) Sleep patterns after carbachol delivery in the ventral oral pontine tegmentum of the cat. Neuroscience 83:1137-1144. CrossRef Medline

George R, Haslett WL, Jenden DJ (1964) A cholinergic mechanism in the brainstem reticular formation: induction of paradoxical sleep. Int J Neuropharmacol 3:541-552. CrossRef Medline

Gerashchenko D, Salin-Pascual R, Shiromani PJ (2001) Effects of hypocretinsaporin injections into the medial septum on sleep and hippocampal theta. Brain Res 913:106-115. CrossRef Medline

Gervasoni D, Lin SC, Ribeiro S, Soares ES, Pantoja J, Nicolelis MA (2004) Global forebrain dynamics predict rat behavioral states and their transitions. J Neurosci 24:11137-11147. CrossRef Medline

Gnadt JW, Pegram GV (1986) Cholinergic brainstem mechanisms of REM sleep in the rat. Brain Res 384:29-41. CrossRef Medline

Grace KP, Liu H, Horner RL (2012) 5-HT1A receptor-responsive pedunculopontine tegmental neurons suppress REM sleep and respiratory motor activity. J Neurosci 32:1622-1633. CrossRef Medline

Grace KP, Hughes SW, Horner RL (2014) Identification of a pharmacological target for genioglossus reactivation throughout sleep. Sleep 37:41-50. CrossRef Medline

Hobson JA, Goldberg M, Vivaldi E, Riew D (1983) Enhancement of desynchronized sleep signs after pontine microinjection of the muscarinic agonist bethanechol. Brain Res 275:127-136. CrossRef Medline

Huitron-Resendiz S, Kristensen MP, Sánchez-Alavez M, Clark SD, Grupke SL, Tyler C, Suzuki C, Nothacker HP, Civelli O, Criado JR, Henriksen SJ, Leonard CS, de Lecea L (2005) Urotensin II modulates rapid eye movement sleep through activation of brainstem cholinergic neurons. J Neurosci 25:5465-5474. CrossRef Medline

Imeri L, Bianchi S, Angeli P, Mancia M (1994) Selective blockade of different brain stem muscarinic receptor subtypes: effects on the sleep-wake cycle. Brain Res 636:68-72. CrossRef Medline

Jones BE (1979) Elimination of paradoxical sleep by lesions of the pontine gigantocellular tegmental field in the cat. Neurosci Lett 13:285-293. CrossRef Medline

Knight BW (1972) Dynamics of encoding in a population of neurons. J Gen Physiol 59:734-766. CrossRef Medline

Lai YY, Siegel JM (1991) Pontomedullary glutamate receptors mediating locomotion and muscle tone suppression. J Neurosci 11:2931-2937. Medline

Lu J, Sherman D, Devor M, Saper CB (2006) A putative flip-flop switch for control of REM sleep. Nature 441:589-594. CrossRef Medline

Maloney KJ, Mainville L, Jones BE (1999) Differential c-Fos expression in cholinergic, monoaminergic, and GABAergic cell groups of the pontomesencephalic tegmentum after paradoxical sleep deprivation and recovery. J Neurosci 19:3057-3072. Medline

Mastrangelo D, de Saint Hilaire-Kafi Z, Gaillard JM (1994) Effects of clonidine and alpha-methyl-p-tyrosine on the carbachol stimulation of paradoxical sleep. Pharmacol Biochem Behav 48:93-100. CrossRef Medline

McCarley RW, Hobson JA (1971) Single neuron activity in cat gigantocel- 
lular tegmental field: selectivity of discharge in desynchronized sleep. Science 174:1250-1252. CrossRef Medline

Mitler MM, Dement WC (1974) Cataplectic-like behavior in cats after micro-injections of carbachol in pontine reticular formation. Brain Res 68:335-343. CrossRef Medline

Natschlager T, Markram H, Maass W (2003) Computer models and analysis tools for neural microcircuits. In: Neuroscience databases, pp 123-138. New York: Springer.

Pace-Schott EF, Hobson JA (2002) The neurobiology of sleep: genetics, cellular physiology and subcortical networks. Nat Rev Neurosci 3:591-605. CrossRef Medline

Pal D, Mallick BN (2009) GABA in pedunculopontine tegmentum increases rapid eye movement sleep in freely moving rats: possible role of GABAergic inputs from substantia nigra pars reticulata. Neuroscience 164:404414. CrossRef Medline

Paxinos G, Watson C (1998) The rat brain in stereotaxic coordinates, Ed 4. San Diego: Academic.

Pollock MS, Mistlberger RE (2003) Rapid eye movement sleep induction by microinjection of the GABA-A antagonist bicuculline into the dorsal subcoeruleus area of the rat. Brain Res 962:68-77. CrossRef Medline

Quattrochi JJ, Mamelak AN, Madison RD, Macklis JD, Hobson JA (1989) Mapping neuronal inputs to REM sleep induction sites with carbacholfluorescent microspheres. Science 245:984-986. CrossRef Medline

Sakai K, Koyama Y (1996) Are there cholinergic and non-cholinergic paradoxical sleep-on neurones in the pons? Neuroreport 7:2449-2453. CrossRef Medline

Sanford LD, Tang X, Xiao J, Ross RJ, Morrison AR (2003) GABAergic regulation of REM sleep in reticularis pontis oralis and caudalis in rats. J Neurophysiol 90:938-945. CrossRef Medline

Sapin E, Lapray D, Bérod A, Goutagny R, Léger L, Ravassard P, Clément O, Hanriot L, Fort P, Luppi PH (2009) Localization of the brainstem GABAergic neurons controlling paradoxical (REM) sleep. PLoS One 4:e4272. CrossRef Medline

Sastre JP, Buda C, Kitahama K, Jouvet M (1996) Importance of the ventrolateral region of the periaqueductal gray and adjacent tegmentum in the control of paradoxical sleep as studied by muscimol microinjections in the cat. Neuroscience 74:415-426. CrossRef Medline

Semba K, Fibiger HC (1992) Afferent connections of the laterodorsal and the pedunculopontine tegmental nuclei in the rat: a retro- and anterograde transport and immunohistochemical study. J Comp Neurol 323: 387-410. CrossRef Medline

Semba K, Reiner PB, Fibiger HC (1990) Single cholinergic mesopontine tegmental neurons project to both the pontine reticular formation and the thalamus in the rat. Neuroscience 38:643-654. CrossRef Medline

Shiromani PJ, McGinty DJ (1986) Pontine neuronal response to local cholinergic infusion: relation to REM sleep. Brain Res 386:20-31. CrossRef Medline

Shiromani PJ, Fishbein W (1986) Continuous pontine cholinergic microinfusion via mini-pump induces sustained alterations in rapid eye movement (REM) sleep. Pharmacol Biochem Behav 25:1253-1261. CrossRef Medline

Stein RB (1965) A theoretical analysis of neuronal variability. Biophys J 5:173-194. CrossRef Medline

Torterolo P, Morales FR, Chase MH (2002) GABAergic mechanisms in the pedunculopontine tegmental nucleus of the cat promote active (REM) sleep. Brain Res 944:1-9. CrossRef Medline

van Dongen PA (1980) Locus ceruleus region: effects on behavior of cholinergic, noradrenergic, and opiate drugs injected intracerebrally into freely moving cats. Exp Neurol 67:52-78. CrossRef Medline

Velazquez-Moctezuma J, Gillin JC, Shiromani PJ (1989) Effect of specific M1, M2 muscarinic receptor agonists on REM sleep generation. Brain Res 503:128-131. CrossRef Medline

Weng FJ, Williams RH, Hawryluk JM, Lu J, Scammell TE, Saper CB, Arrigoni E (2014) Carbachol excites sublaterodorsal nucleus neurons projecting to the spinal cord. J Physiol 592:1601-1617. CrossRef Medline

Yamamoto K, Mamelak AN, Quattrochi JJ, Hobson JA (1990) A cholinoceptive desynchronized sleep induction zone in the anterodorsal pontine tegmentum: locus of the sensitive region. Neuroscience 39:279-293. CrossRef Medline 